\title{
EDUCATION INTERNATIONALIZATION
}

\section{THE SUPPORT OF ACADEMIC MOBILITY OF STUDENTS IN THE SLOVAK REPUBLIC}

\author{
ZUZANA GAZDAČKOVÁ, \\ LUCIA HUPKOVÁ \\ University of Žilina in Žilina, \\ Slovak Republic
}

Keywords: Internationalization, Higher education, Problems, Slovak Republic, University of Žilina in Žilina

\begin{abstract}
The paper deals with problems of internationalisation of higher education in the Slovak Republic with the focus on the University of Žilina in Žilina.

Source: Gazdackova Z., Hupkova L., 2013. "The support of academic mobility of students in the Slovak Republic", Perspectives of Innovations, Economics \& Business, Vol.13(4), pp.74-83, http://dx.doi.org/10.15208/pieb.2013.21
\end{abstract}

\section{Introduction}

The most obvious process that can be observed mainly in the last decades in every area of human life, it does not matter whether we are talking about culture, economics, policy, natural environment or communication is definitely globalization. One of the most typical features of globalization is the collapse of such variables as the time and space, which determine the reality of the whole world itself, as a result of clash of two or more cultures.

When focused on higher education, in the present era of globalization there is one significant phenomenon with still increasing tendency. The phenomenon referred to as the internationalization. In general, this up to date term could be defined as the act of bringing something under the international control. In the case of higher education we are rather talking about the act of making the education international.

There are different ways in which internationalization of higher education is reflected. Especially in higher education more and more students try to gain experience abroad. Many of them consider studying

* The article was reported in PRADEC Interdisciplinary Conference Proceedings. "Internationalisation in Higher Education: Evaluating Concepts, Challenges and Strategies", Prague, April 25-26, 2013 
at a foreign university an important step for their future career. For the students who come from third countries on the temporary stay, later on it is also the opportunity to obtain legal permanent residence in the country of their interest, which may lead to their employment in the European Union after their graduation. That is the reason why these so called international students represent a considerable part of the migrant population in the European Union countries. The 2010 Eurostat data on issued residence permits proved the fact, that the migration to study had already at that time been the third most common reason for immigration to the European Union countries.

Among migrants, foreign students with their own needs, as well as the terms and conditions of migration, are seen as a very specific group. From the perspective of the development of knowledge and skills, as well as their effects on the labour market, their migration may mean great contribution not only for the host but also for the home country. On the other hand, migration of students may pose some risks in the form of abuse of student status in host countries or the so-called risk of brain drain to the student's home country.

It is important to realize that the migration of students does not affect only the education system of countries but it has also a significant impact on other areas of life such as the economy, migration policies and development policies, as well as the labour market as a whole. The demographic aspects should be also taken into account as well as the public opinion.

The Slovak Republic, as a member state of the European Union, is strongly influenced by this membership also concerning the issue of internationalization of higher education. The Council of the European Union places great importance on promoting mobility in terms of higher education students, teaching staff and researchers. "Such mobility is the mean of increasing of intellectual capital and strengthening of employability through gaining and exchanging of knowledge, the development of language and intercultural skills and support of personal contacts."* Such movement of knowledge increasing could furthermore lead to creativity and innovation spreading.

Finding out new knowledge and passing it to students, these are the main aims of the higher education, also from the point of view of the European Commission, which declares that in Europe there can be found 4 ooo higher education institutions, with over 19 million students and 1.5 million staff ${ }^{\dagger}$. In general, in spite of the fact, that some of these European Universities are among the best in the world, the problem of them could be seen in the potential, which is there, but which is not being fully realized because of the lack of management tools and funding.

* Source: Závery Rady o internacionalizácii vysokoškolského vzdelávania.

† Consult: Education and Training. Higher Education in Europe.

- 75 - 
It is assumed that in the future the jobs within the European Union will demand higher education and qualifications. This phenomenon is quite common also at present time. People with university education are of greater chance to succeed on the labour market. Universities must accept this trend and adapt to market requirements. Students' interest in higher education has increased in recent years, as a result of a problem with employment after finishing high school.

We can say that the study at a university represents to some extent filling of students' time, to prevent them sitting at home registered at labour offices. As M. Ferdák said: "...massification has an unprecedented impact on the quality of higher education and its development, respectively its stagnation."

Currently, a graduate has to meet not only the requirements in relation to knowledge, but also to the development of creativity and critical thinking. The primary objective of higher education should therefore be an effort to modernize the educational system in the Slovak Republic in terms of finding the interconnection between theory and practice. The initiative of increasing of an attractiveness of the knowledge economy is largely associated with mobility of study or work stays.

In the Slovak Republic, as well as in a whole globalized world, students mobility is becoming a big part of this initiative as an important tool for acquiring skills for practice, which provides the opportunity to see different approaches and procedures, it enables to perceive other cultural environments, ultimately would bring positive changes. The great advantage for the student is not only the study abroad, but mainly their developing of practical skills.

The umbrella document in the case of Slovak Republic is the Programme Declaration of the Government of the Slovak Republic for the years 2012 - 2016, in which the Government also declares support of the mobility of students, teachers and researchers, as well as the support for legislative changes to ensure such conditions "...to quality students and researchers from the third countries coming to study and work in Slovakia." ${ }^{\prime}$

The Ministry of Education, Science, Research and Sport of the Slovak Republic prepares and annually updates and publishes a long-term plan in the educational, research, development, artistic and other creative activities of higher education institutions.

Currently there is in force a long-term plan of the Ministry till the year 2014, which, within the topic of this study indicates the intention to increase the attractiveness of Slovak universities, also through the intensification of cooperation with foreign universities, establishing of

* Fedák, M., Ako d’alej so slovenským vysokým školstvom. In: Európa 2020 - inteligentná, udržatel'ná a inkluzívna Európa - odporúčania pre Slovensko.

† Source: Znalostná spoločnost', vzdelávanie a kultúra. 
joint study programs, as well as increasing mobility of students and university teachers between Slovak and foreign universities.

In recent years, three broad strategic documents, dealing with political intention of internationalization of higher education and encouraging mobility of students and researchers developed into tasks, were signed in Slovakia. Some of them have already been partially or fully implemented, respectively continuously realized.

These documents are: Minerva 2.0 - Slovakia into the first league, Migration policy of the Slovak Republic, Perspective until the year 2020 and Medium-term strategy for Official Development Assistance of the Slovak Republic for the years 2009-2013 and its constituent annual National development assistance programs.

SAIA, n. o. plays an important role in the stay of foreigners - foreign students in Slovakia. Slovak Academic Information Agency is a nongovernmental non-profit organisation, which in addition to providing advisory service on opportunities for study abroad and also organizes specialized seminars, workshops and public discussions to develop or strengthen cooperation and exchange of experience among those interested in any kind of academic mobility within its programmes: Academic Mobility; CEEPUS; Action Austria - Slovakia; National Scholarship Programme; NIL Fund (Norwegian/EEA Financial Mechanisms), Sciex (Swiss-Slovak Scholarship Fund), EURAXESS Services Centres.

For all we can mention its annual conferences: The Day of Academic Mobility and Internationalization*. Within these there is regularly discussed the issue of stay of foreign students, $\mathrm{PhD}$. students, researchers, the opportunity for scholarship support and there is also a discussion about the opportunities and tools of improving the attractiveness of Slovakia for foreign students and researchers. The aim of the events is to provide employees of universities and research organizations who are professionally involved in international cooperation and internationalization of their institutions, discussion with key representatives of public sector and non-profit sector about actual problem areas of their operation, as well as to provide information on new policies, changes in legislation and support programs in Slovakia.

The need to increase the level of higher education in Slovakia was discussed at a workshop the Youth on the move. It was the thematic workshop of the series Europe 2020, that dealt with the attractiveness of higher education in the Slovak Republic, of which integral part represents the mobility of students, in order to increase their competence.

\footnotetext{
* The first conference Internationalization as a Tool of Strengthening of the Quality of Education and Research, took place in December 2010 and the second conference The Day of Academic Mobility and Internationalization II, one year later, in December 2011.
} 
The topic of internationalization of higher education is also in the focus of the Slovak Academic Association for International Cooperation. SAAIC is a voluntary association, whose objective is to support and coordinate international cooperation of Slovak universities and other institutions, especially with the European Union countries within the framework of educational and other programmes. It is also known as the National Agency of the Lifelong Learning Programme of the European Union, and in the same way the office of the Erasmus programme. Although the activities of SAAIC are mainly focused on mobility within the EU, marginally their activities are also aimed at foreigners from third countries.

The national seminar Internationalization of higher education in Slovakia from $13^{\text {th }}$ of May 2010, which was devoted to a great extent, to universities and foreign students from third countries could be highlighted from the activities of the last years.

The conclusions of national seminar are still topical, whereas the recommendations for actions at the national, but also at the institutional level, for example the need to develop a strategy for the development and promotion of the internationalization of higher education and the involvement of Slovak universities in international cooperation, the need to develop a methodology for assessing the quality of internationalization of higher education and its consideration in the evaluation of function of higher education institutions and the accreditation (not only in terms of participation in research, but also in terms of participation in international educational activities), to develop a methodology of training and accreditation of joint study programs, the need to establish and strengthen the institutional and financial arrangements for mobility of students, and to solve administrative and visa problems related to the stay of students from outside the EU in the Slovak Republic.

In the area of international cooperation Faculty of Humanities cooperates with foreign institutions in scientific research, artistic and educational fields. International cooperation is carried out mainly on the basis of:

1. Bilateral agreements within the programme of the LLP Erasmus

2. Through the so-called. direct agreements

3. Through grant schemes supporting international activities in the field of higher education, or individual participation of researchers and lecturers of FHV in international scientific, artistic, professional organizations, associations, committees, councils, etc.

Programme Erasmus LLP, which focuses on improving the quality of higher education through international university cooperation, is regarded as the most successful program aimed at exchange of students.

The University of Žilina began the cooperation with the Erasmus programme in 1998. In 2007, the University started to participate in the Lifelong Learning Programme, by which it has been granted extended Erasmus University Charter, which enabled further development of cooperation not only in university exchange of students and lecturers, 
but also in administrative and more intensive cooperation with businesses in student mobility. Under this program, the University has the opportunity to coordinate and realize the Erasmus mobility from one centre.

The University recognizes the need to improve the quality of higher education; therefore, it puts great emphasis on making outgoing mobility, with the help of which in comparison with other universities in Slovakia obtained the first place in the number of outgoing students and teachers on training programs and mobility. In 2012 the University was awarded the prestigious award the Quality of Erasmus Mobility 2012.

Through the study stay students have the opportunity to acquire new skills. They are able to better adapt to the new environment and have the opportunity to gain a perspective for application in practice. In this context, it is necessary to mention the realization of practical stay that begins to be increasingly important in higher education.

Now we will focus on the mobility offered to students and staff of the Faculty of Humanities of the University of Žilina in Žilina. Fundamental attributes of the current and subsequent development of international cooperation and foreign scientific, educational and vocational projects and grants for the Faculty of Humanities of the University of Zilina in Žilina, are: quality, active involvement in the foreign partnership, progressive growth and openness to collaboration with strong foreign higher education institutions.

Besides the individual participation of academic staff and lecturers of this faculty at work on international projects, the Faculty of Humanities was involved in an international project Lifelong Learning Programme Leonardo PaCTT Project in the year 2012. Foreign partners of this project are: Birmingham City University (UK), Paris Chambers of Commerce (France), National Institute for Training and Career Development in Education (NIOKSO) (Bulgaria), University of Beira Interior (Portugal) and Capa Anatolian Teacher Training High School (Turkey).

Another international project that was successfully completed by the Faculty at their ground in the year 2012 was the26th World Congress of the Czechoslovak Society of Arts and Sciences with its seat in the United States under the name of the $S V U$ and its role in the era of globalization: Transatlantic cooperation, innovation and preservation.

Through cooperation of the Faculty of Humanities of the University of Žilina in Žilina, Prešov University in Prešov, and Roanoke College, Center for Religion and Society, USA has also performed a scientific project within the transatlantic cooperation in the field of religious studies.

In order to provide the most current information about the student stays and outgoing, as well as incoming students and academic staff, we have chosen the period of 2009 - 2012, that could be seen in the Table 1 . In the focus of attention of the Faculty there is the development of international relations, by the following indicators: 
- Bilateral agreements

- Outgoing academic staff

- Outgoing administrative staff

- Incoming foreign visitors (scholars)

- Incoming foreign students

- Incoming administrative staff

- Outgoing students - study stays Erasmus LLP

- Practical stays Erasmus LLP - outgoing students

TABLE 1. OVERVIEW OF INTERNATIONAL RELATIONS AT THE FACULTY OF HUMANITIES OF THE UNIVERSITY OF ŽILINA IN ŽILINA

\begin{tabular}{lcccc}
\hline Overall overview & 2009 & 2010 & 2011 & 2012 \\
\hline Bilateral agreements & 20 & 22 & 28 & 36 \\
\hline Outgoing students - study stays Erasmus LLP & 10 & 18 & 22 & 35 \\
\hline $\begin{array}{l}\text { Outgoing students - practical training Erasmus } \\
\text { LLP }\end{array}$ & 2 & 1 & 1 & 2 \\
\hline Incoming students & 4 & 1 & 5 & 9 \\
\hline Outgoing academic staff & 9 & 12 & 21 & 13 \\
\hline Outgoing administrative staff & 1 & 1 & 0 & 1 \\
\hline Incoming administrative staff & 4 & 1 & 1 & 1 \\
\hline Incoming foreign visitors (scholars) & 17 & 11 & 18 & 20 \\
\hline
\end{tabular}

Trend in the higher number of outgoing students compared with incoming ones, which is noticeable in the whole Slovak Republic, also applies to the Faculty of Humanities of the University of Žilina in Žilina. Since 2009 there is an increase in the demand as well as the realization of the outgoing mobility outwards from Slovakia. While in 2009 the number of outgoing students through the Erasmus program was 10 and it was 20 on the basis of bilateral agreements, in 2012, the number of students increased to 35 through the Erasmus program and to 36 through bilateral agreements.

\section{TABLE 2. POSSIBILITIES OF MOBILITY AT THE FACULTY OF HUMANITIES OF THE UNIVERSOITY OF ŽILINA IN ŽILINA}

\begin{tabular}{|c|c|c|c|}
\hline $\begin{array}{l}\text { The Name of } \\
\text { Foreign } \\
\text { University }\end{array}$ & Town/State & $\begin{array}{l}\text { Study programme } \\
\text { Mobility - students }\end{array}$ & $\begin{array}{l}\text { Study programme } \\
\text { Mobility - lecturers }\end{array}$ \\
\hline $\begin{array}{l}\text { Hogskolen i } \\
\text { Telemark }\end{array}$ & Telemark/ Norway & $\begin{array}{l}\text { 15.0 Communication and } \\
\text { Information Science } \\
\text { Modern EC languages } \\
\text { Linguistics } \\
\text { Environmental Sciences }\end{array}$ & $\begin{array}{l}\text { 15.0 Communication and } \\
\text { Information Science } \\
\text { Modern EC languages } \\
\text { Linguistics } \\
\text { Environmental Sciences/Ecology }\end{array}$ \\
\hline $\begin{array}{l}\text { Linköpings } \\
\text { Universitet }\end{array}$ & Linköping/Šweden & 46 Mathematics, Informatics & 46 Mathematics, Informatics \\
\hline Diaconia & Helsinki/Fínland & $\begin{array}{r}762 \text { Social work } \\
-80-\end{array}$ & 762 Social work \\
\hline
\end{tabular}




\section{TABLE 2. POSSIBILITIES OF MOBILITY AT THE FACULTY OF HUMANITIES OF THE UNIVERSOITY OF ŽILINA IN ŽILINA}

\begin{tabular}{|c|c|c|c|}
\hline $\begin{array}{l}\text { The Name of } \\
\text { Foreign } \\
\text { University }\end{array}$ & Town/State & $\begin{array}{l}\text { Study programme } \\
\text { Mobility - students }\end{array}$ & $\begin{array}{l}\text { Study programme } \\
\text { Mobility - lecturers }\end{array}$ \\
\hline $\begin{array}{l}\text { university of } \\
\text { applied sciences }\end{array}$ & & 221 Theology & 221 Theology \\
\hline $\begin{array}{l}\text { University of } \\
\text { Turin }\end{array}$ & Torino/Italy & 46 Mathematics, Informatics & 46 Mathematics, Informatics \\
\hline $\begin{array}{l}\text { Universita degli } \\
\text { studi di Genova }\end{array}$ & Genova/Italy & $\begin{array}{l}322 \text { Library, Information, Archive } \\
3221 \text { Documentation;Teacher } \\
\text { Training and Education Science; } \\
\text { Foreign languages }\end{array}$ & $\begin{array}{l}322 \text { Library, Information, Archive } \\
3221 \text { Documentation;Teacher } \\
\text { Training and Education Science; } \\
\text { Foreign languages }\end{array}$ \\
\hline $\begin{array}{l}\text { University of } \\
\text { Granada }\end{array}$ & Granada/Spain & 14 Education, Teacher training & 14 Education, Teacher training \\
\hline $\begin{array}{l}\text { Instituto } \\
\text { Superior Da } \\
\text { MAIA }\end{array}$ & $\begin{array}{l}\text { Castelo Da } \\
\text { Maia/Portugal }\end{array}$ & $\begin{array}{l}\text { 03.0 Art and Design } \\
22 \text { Humanities }\end{array}$ & $\begin{array}{l}\text { 03.0 Art and Design } \\
22 \text { Humanities }\end{array}$ \\
\hline $\begin{array}{l}\text { Hochshule } \\
\text { Mittweida }\end{array}$ & Mittweida/Germany & 46 Mathematics, Informatics & 46 Mathematics, Informatics \\
\hline $\begin{array}{l}\text { Kirchliche } \\
\text { Pädagogische } \\
\text { Hochschule } \\
\text { Wien/Krems }\end{array}$ & Vienna/Austria & $\begin{array}{l}\text { 14;222 Teacher training and } \\
\text { education science; Foreign } \\
\text { languages }\end{array}$ & $\begin{array}{l}\text { 14;222 Teacher training and } \\
\text { education science; Foreign } \\
\text { languages }\end{array}$ \\
\hline Marnix Academie & eUtrecht/Netherlands & $\begin{array}{l}\text { 14;222 Teacher training and } \\
\text { education science; Foreign } \\
\text { languages }\end{array}$ & $\begin{array}{l}\text { 14;222 Teacher training and } \\
\text { education science; Foreign } \\
\text { languages }\end{array}$ \\
\hline $\begin{array}{l}\text { University of } \\
\text { Patras }\end{array}$ & Patras/Greece & $\begin{array}{l}46 \text { Mathematics, Informatics } \\
34 \text { Business and administration } \\
342 \text { Marketing and advertising } \\
481 \text { Computer Science } \\
\text { 14;22 Teacher training and } \\
\text { education science; Humanities; } \\
\text { 226 Philosophy and ethics }\end{array}$ & $\begin{array}{l}46 \text { Mathematics, Informatics } \\
34 \text { Business and administration } \\
342 \text { Marketing and advertising } \\
481 \text { Computer Science } \\
\text { 14;22 Teacher training and } \\
\text { education science; Humanities; } \\
\text { 226 Philosophy and ethics }\end{array}$ \\
\hline $\begin{array}{l}\text { Univerzita } \\
\text { Palackého v } \\
\text { Olomouci } \\
\end{array}$ & $\begin{array}{l}\text { Olomouc, Čzech } \\
\text { Republic }\end{array}$ & $\begin{array}{l}14 \text { Teacher training and } \\
\text { education science }\end{array}$ & $\begin{array}{l}14 \text { Teacher training and } \\
\text { education science }\end{array}$ \\
\hline $\begin{array}{l}\text { Masarykova } \\
\text { univerzita v Brně }\end{array}$ & Brno/ Čzech Republic & $\begin{array}{l}212 \text { Music and Musicology } \\
46 \text { Mathematics, statistics }\end{array}$ & $\begin{array}{l}212 \text { Music and Musicology } \\
46 \text { Mathematics, statistics }\end{array}$ \\
\hline $\begin{array}{l}\text { Ostravská } \\
\text { univerzita v } \\
\text { Ostrave } \\
\end{array}$ & $\begin{array}{l}\text { Ostrava/ Čzech } \\
\text { Republic }\end{array}$ & 212 Music and Performing arts & 212 Music and Performing arts \\
\hline $\begin{array}{l}\text { Západočeská } \\
\text { univerzita v Plzni }\end{array}$ & Plzeň, Čzech Republic & $\begin{array}{l}212 \text { Music and Musicology } \\
14 \text { Teacher training and } \\
\text { education science }\end{array}$ & $\begin{array}{l}212 \text { Music and Musicology } \\
14 \text { Teacher training and } \\
\text { education science }\end{array}$ \\
\hline $\begin{array}{l}\text { Univerzita Jana } \\
\text { Evangelisty } \\
\text { Purkynì v Ústí } \\
\text { nad Labem } \\
\end{array}$ & $\begin{array}{l}\text { Ústí nad Labem/ } \\
\text { Čzech Republic }\end{array}$ & 03.2 Music and Musicology & 03.2 Music and Musicology \\
\hline $\begin{array}{l}\text { Silesian } \\
\text { University in } \\
\text { Opava }\end{array}$ & $\begin{array}{l}\text { Opava/ Čzech } \\
\text { Republic }\end{array}$ & $\begin{array}{l}15.4 \text { Library Science; } \\
\text { Communication and Information } \\
\text { Science }\end{array}$ & $\begin{array}{l}\text { 15.4 Library Science; } \\
\text { Communication and Information } \\
\text { Science }\end{array}$ \\
\hline
\end{tabular}




\section{TABLE 2. POSSIBILITIES OF MOBILITY AT THE FACULTY OF HUMANITIES OF THE UNIVERSOITY OF ŽILINA IN ŽILINA}

\begin{tabular}{|c|c|c|c|}
\hline $\begin{array}{l}\text { The Name of } \\
\text { Foreign } \\
\text { University }\end{array}$ & Town/State & $\begin{array}{l}\text { Study programme } \\
\text { Mobility - students }\end{array}$ & $\begin{array}{l}\text { Study programme } \\
\text { Mobility - lecturers }\end{array}$ \\
\hline $\begin{array}{l}\text { Vysoké učení } \\
\text { technické v Brně }\end{array}$ & Brno/ Čzech Republic & $\begin{array}{l}46 \text { Mathematics, Informatics } \\
\text { o3.2 Music and musicology }\end{array}$ & $\begin{array}{l}\text { 46 Mathematics, Informatics } \\
\text { o3.2 Music and musicology }\end{array}$ \\
\hline $\begin{array}{l}\text { Janáèkova } \\
\text { akademie } \\
\text { múzických umìní }\end{array}$ & Brno/ Čzech Republic & $\begin{array}{l}\text { 221;14 Music and performing art } \\
\text { Teacher training and education } \\
\text { science }\end{array}$ & $\begin{array}{l}\text {;221;14 Music and performing arts; } \\
\text { Teacher training and education } \\
\text { science }\end{array}$ \\
\hline $\begin{array}{l}\text { Karlova } \\
\text { Univerzita } \\
\text { v Prahe }\end{array}$ & $\begin{array}{l}\text { Praha / Čzech } \\
\text { Republic }\end{array}$ & & \\
\hline $\begin{array}{l}\text { University of } \\
\text { Silesia }\end{array}$ & Katowice/Poland & 11 Mathematics & 11 Mathematics \\
\hline $\begin{array}{l}\text { Uniwersytet } \\
\text { Opolski }\end{array}$ & Opole/Poland & 31 Social and behavioural science & 31 Social and behavioural sciences \\
\hline $\begin{array}{l}\text { Poznan } \\
\text { University of } \\
\text { Technology }\end{array}$ & Poznan/Poland & 11 Mathematics & 11 Mathematics \\
\hline $\begin{array}{l}\text { Akademia im. } \\
\text { Jana Dlugosza w } \\
\text { Czestochowie }\end{array}$ & Czestochowa/Poland & $\begin{array}{l}46 \text { Mathematics } \\
222 \text { Modern EC languages } \\
212 \text { Music and musicology } \\
762 \text { Social work (pedagogy) }\end{array}$ & $\begin{array}{l}46 \text { Mathematics } \\
222 \text { Modern EC languages } \\
212 \text { Music and musicology } \\
762 \text { Social work (pedagogy) }\end{array}$ \\
\hline $\begin{array}{l}\text { Panstwowa } \\
\text { Wysza szkola } \\
\text { Zawodowa }\end{array}$ & Wloclawek/Poland & 222 Foreign languages & 222 Foreign languages \\
\hline $\begin{array}{l}\text { Akademia } \\
\text { Muzyczna im. } \\
\text { Karola } \\
\text { Lipiñskiego } \\
\end{array}$ & Wroc ${ }^{3}$ av/Poland & $\begin{array}{l}\text { 03.2; Music and Musicology; } \\
\text { 3.2;14 } 14 \text { Teacher training and } \\
\text { education science }\end{array}$ & $\begin{array}{l}\text { 03.2; Music and Musicology; } \\
3.2 ; 1414 \text { Teacher training and } \\
\text { education science }\end{array}$ \\
\hline $\begin{array}{l}\text { University Of } \\
\text { Natural Sciences } \\
\text { and Humanities }\end{array}$ & Siedlce/Poland & $\begin{array}{l}14 \text { Education, Teacher Training } \\
222 \text { Foreign languages } \\
46 \text { Mathematics and statistics }\end{array}$ & $\begin{array}{l}14 \text { Education, Teacher Training } \\
222 \text { Foreign languages } \\
46 \text { Mathematics and statistics }\end{array}$ \\
\hline $\begin{array}{l}\text { Eszterházy } \\
\text { Károly Föiskola }\end{array}$ & Eger/Hungary & $\begin{array}{l}222 \text { English language } \\
322 \text { Library Science }\end{array}$ & $\begin{array}{l}46 \text { Mathematics, Informatics } \\
322 \text { Library Science } \\
212 \text { Music and Musicology }\end{array}$ \\
\hline $\begin{array}{l}\text { University of } \\
\text { Tartu }\end{array}$ & Narva/Estonia & $\begin{array}{l}14 \text { Education, Teacher Training } \\
22 \text { Humanities }\end{array}$ & $\begin{array}{l}14 \text { Education, Teacher Training } \\
22 \text { Humanities }\end{array}$ \\
\hline Kafkas University & yKars/Turkey & 222 English language & 222 English language \\
\hline $\begin{array}{l}\text { Karabûk } \\
\text { University }\end{array}$ & Karabûk/ Turkey & $\begin{array}{l}222 \text { Foreign language and } \\
\text { literature } \\
46 \text { Mathematics } \\
212 \text { Music and Performing arts }\end{array}$ & $\begin{array}{l}222 \text { Foreign language and } \\
\text { literature } \\
46 \text { Mathematics } \\
212 \text { Music and Performing arts }\end{array}$ \\
\hline
\end{tabular}

A number of students who are interested in mobility differs from the number of students who have actually travelled abroad primarily because of the need of the financial participation on stay or for their finishing university studies. For instance in the academic year 
2012/2013, 47 students asked for the grant, but 14 students of them cancelled their application.

Most visited countries of the Slovak outgoing students are: Czech Republic, Greece, Portugal, and Norway. More information on possibilities of studying at foreign universities could be seen in Table 2 . Possibilities of mobility at the Faculty of Humanities of the University of Žilina in Žilina.

Although coordinators at the Faculty of Humanities of the University of Žilina in Žilina are trying to make study stays for students more attractive through stays abroad and helping students with providing answers and dealing with problems, that are facing even in the time of their ensuring of stay, accommodating students in addressing issues and problems, facing them while still handling your stay. There are certain disagreements arising primarily from incompatibility of study programs, resulting in the recognition of subjects which a student fails to pass at the stay, because of the lack of concord of the number of credits or the lack of appropriate subject at all.

\section{References}

Education and Training. Higher Education in Europe, Retrieved 20.04.2013 http://ec.europa.eu/education/lifelong-learning-policy/higher_en.htm

Fedák, M., Ako d’alej so slovenským vysokým školstvom, In: Európa 2020 - inteligentná, udržatel'ná a inkluzívna Európa - odporúčania pre Slovensko, Retrieved 20.04.2013 http://www.refernet.sk/images/news/files/europa-2020-inteligentna-udrzatelna-ainkluzivna-europa.pdf

Úrad vlády Slovenskej republiky. Znalostná spoločnost', vzdelávanie a kultúra. , in Slovak, Retrieved 20.04.2013 http://www.vlada.gov.sk/znalostna-spolocnost-vzdelavanie-a-kultura/

Závery Rady o internacionalizácii vysokoškolského vzdelávania, in Slovak, Retrieved 20.04.2013 from http://www.minedu.sk/data/att/2297.pdf 